Article

\title{
Valuing Agricultural Landscape: Lithuanian Case Study Using a Contingent Valuation Method
}

\author{
Anastasija Novikova ${ }^{1, *}$, Lucia Rocchi ${ }^{2}$ and Bernardas Vaznonis ${ }^{1}$ \\ 1 Research Institute for Bioeconomy, Vytautas Magnus University, LT-53361 Kaunas District, Lithuania; \\ bernardas.vaznonis@vdu.lt \\ 2 Department of Agricultural, Food and Environmental Sciences, University of Perugia, 74-06121 Perugia, \\ Italy; lucia.rocchi@unipg.it \\ * Correspondence: anastasija.novikova@vdu.lt; Tel.: +370-6726-1959
}

Received: 25 March 2019; Accepted: 6 May 2019; Published: 9 May 2019

\begin{abstract}
This study analyses Lithuanian residents' willingness to pay (WTP) for the agricultural landscape in Lithuania. Since it is a part of the European Union, the agriculture is supported by the Common Agricultural Policy (CAP). According to CAP, agri-environmental schemes focus on the maintenance and improvement of agricultural landscape. Under these measures, Lithuanian farmers receive payments for the creation of agricultural landscape services. Therefore, understanding the demand of such agricultural landscape services, as received by the society, may help policymakers better allocate the funds. The present study has revealed that Lithuanian residents are concerned about the maintenance and preservation of the agricultural landscape. Moreover, they demand provision of the agricultural landscape services. Application of the contingent valuation method has shown that the median WTP of $23.59 € /$ year per family for agricultural landscape services, which is influenced by socioeconomic characteristics. The findings of the present study provide quantitative information about the demand for agricultural landscape services, which could be used to improve the agri-environmental policy, substantiating the internalization of positive and negative externalities (e.g., agricultural landscape services) to the performance of farmers.
\end{abstract}

Keywords: contingent valuation; willingness to pay; agricultural landscape; Lithuania

\section{Introduction}

Agriculture provides society with goods and services, such as food and fibre, as well as cultural, environmental, and other nonmarket goods and services, such as aesthetic value of the landscape, which supply public benefit [1]. Landscape as perceived by people means an area, the characteristics of which are the result of the action and interaction of natural and/or human factors [2]. It plays an important role in cultural, environmental, and social areas, and is a favourable resource for the economy [3]. Landscapes, as amenities, are defined as location-specific features that enhance the attractiveness of a given location. They are important for human well-being, quality of life, and the economic competitiveness of rural areas [4].

Landscape services contribute to rural vitality and economic performance: they are the functional links between landscapes and socio-economic benefits [5]. In the recent years, the demand of urban population for landscape amenities has been increasing. The so-called "neo-rurals", who have greater income than rural residents, look for living and leisure activities in rural areas-outdoor recreation, establishment of the second residence [6]. In terms of tourism and recreation purposes, there is a particular interest in traditional agricultural landscapes because of their historical and cultural value, which generates an additional income [7]. 
To highlight the special role of the landscape for people, several authors [8-12] have used the term 'landscape services' to highlight the human benefit received from the adaption of the landscape to their use, related to economic activities and recreation. This concept also reveals that farmers are service providers to and benefit from the landscape [12]. In the majority of cases, the farmers are more skilled and have more knowledge to manage the natural environment compared to other economic actors [13]. Moreover, agricultural landscape is usually a cultural landscape as well, because historically, it was formed by traditional agricultural production and survival activities [14]. Thus, an agricultural landscape is the evident output of the interaction among farming, ecosystems, and cultural values $[9,11,12,15-20]$.

Agricultural landscapes affect regional development in a way far beyond the production of agricultural commodities [21]. Quality of landscape is a positive (or negative) externality and joint product of farming $[7,22]$. The good farming practices have the potential to significantly increase the value of landscape. Farmers, in this case, create environmental public goods: The extensive land use determines the open landscape, the cultural areas are preserved, and the grazing livestock maintains a large variety of animals in meadows and pastures [13]. At the same time, the process of intensification of agricultural activities could have a detrimental effect on landscape services and reduce the recreational potential. The landscape could become monotonous, continually lose its aesthetic value, and experience reduction in biodiversity because of, for example, the overuse of pesticides and fertilisers [23].

As landscape services are agricultural non-market services, farmers are not interested in providing society with them [24]. Therefore, the absence of economic incentives and their incorrect distribution could lead to the degradation of the landscape and its services [14,20]. However, in some cases, the importance of non-marketable, socio-cultural and environmental public good-type ecosystem services outweighs the importance of agricultural production [20]. Therefore, the evaluation of non-monetary values of agricultural landscapes could be useful to improve the management of agricultural landscapes. Monetary valuation of agricultural landscapes is the basis for economic assessment of landscape services. Tagliaferro et al. [25] noticed that it provides significant information, which allows for the determination of effective amounts for subsidies, taxes, tariffs, and other market regulation measures. Values of agricultural landscape services usually are assessed by employing stated preference methods, such as contingent valuation $(\mathrm{CV})$ or choice experiments (CE). The literature has focused on consumers' willingness to pay (WTP) for the landscape, aesthetic value, when used for leisure time and recreation [26-28] and cultural services with historic and cultural value and cultural heritage and identity $[29,30]$; preservation of the agricultural landscape, preservation of biodiversity, and conservation [1,31-34]; or covering all these aspects [14,35]. Results have usually been used to suggest agri-environmental policy improvements at a national or regional scale.

In this context, the aim of this study is to understand the WTP of Lithuanian residents for the agricultural landscape. Moreover, the study attempts to value the benefits the residents may derive from the management of landscape by farmers and answer the following three questions: (1) What are nonmarket values of agricultural landscape services within the study area; (2) which socioeconomic and knowledge characteristics of respondents determine the willingness to pay, and (3) how can such information regarding consumer preferences be used to improve the targeting the national expenditure for AES.

The paper is structured as follows: Section 2 describes the main features of agricultural landscape in Lithuania, Section 3 explains the methodology applied in the research, Section 4 discusses the results of the empirical application, and Section 5 presents the main conclusions. 


\section{Materials and Methods}

\subsection{Case Study: Lithuanian Agricultural Landscape}

Lithuania covers the area of $65,000 \mathrm{~km}^{2}$, and $85 \%$ of this territory is rural. The total population of Lithuania is approximately 3 million, and more than $30 \%$ of the residents live in rural areas. The agriculture, forestry, and food industry accounts for nearly $4 \%$ of GDP. Notably, $52.41 \%$ of the surface land features agricultural land, and arable land covers $46.76 \%$ [36].

There are natural handicaps in some agricultural areas of Lithuania: These handicaps are a threat to the use of agricultural land and could cause the abandonment of such territories. Therefore, farming in these areas should be managed to maintain a viable village, preserve and improve the local environment, maintain the landscape, and retain the potential areas for tourism. Approximately $60 \%$ of the utilised agricultural area is covered by less favourable areas [37].

Tourism is an alternative activity in rural areas, especially for less favourable agriculture areas. The expansion of tourism services in Lithuania is determined by natural and high value landscapes, historical and cultural values, and the maintained unique attributes of rurality. The number of rural tourism locations has increased by approximately $15 \%$ in the last five years, the variety of the services offered continues to increase [38].

Approximately $25 \%$ of Lithuania is covered by high nature value (HNV) territories, which substantially contribute to the preservation of biodiversity, maintenance of habitats, and preservation of rare species. HNV territories cover approximately $13 \%$ of the Lithuanian territory. Farming in these areas is managed with environmental restrictions to preserve biodiversity [39]. Another type of farming that focuses on preservation of biodiversity and food safety is organic farming. The number of organic farms has been steadily increasing, from nine organic farms in 1993 cultivating 148 ha to 2725 farms in 2017 that cover almost more than 234,000 ha (The data was taken from the Official Statistics portal Statistics Lithuania, available at https://www.stat.gov.lt/home).

The European Union Common Agricultural Policy has specific economic initiatives to preserve, maintain, and avoid detrimental effects to the agricultural landscape: 'agri-environment and climate' measures; organic farming; payments to farmers in areas with handicaps, other than in mountain areas; and greening and other environmental measures. In Lithuania, the measures of the second pillar of the European Union Common Agricultural Policy are related to the preservation of ecosystem services in the agricultural landscape. For instance, Axis II focused on improving the environment and countryside in the Lithuanian Rural Development programme from 2007-2013.

In this study, the landscape stewardship scheme was fully related to the preservation, maintenance, and improvement of the agricultural landscape. The amount distributed to farmers was 78,733 million EUR. Current agri-environmental policy focuses on restoring, preserving, and enhancing the ecosystems related to agriculture, for example, the measures on the 'agri-environment and climate' and 'organic farming' have accounted for more than 220 million EUR. However, even these measures do not always provide the expected results for the society, because farmers usually declare themselves as the creators of commodity outputs and react to additional economic incentives to create landscape services, but insufficiently. Moreover, although a substantial amount of financial support from the European Union and attention to agri-environmental policy have been received, insufficient attention has been given to Lithuanian society and their opinion and understanding of the agricultural landscape and preferences for landscape services. Therefore, understanding and analysing Lithuanian residents' opinions and preferences on landscape services could be useful to improve the allocation of agri-environmental policy.

\subsection{Contingent Valuation and the Survey Design}

The study applied Contingent Valuation method for measuring the discrete value of agricultural landscape externalities produced by conservation of the actual level of management, as in [40]. CV has been widely used to elicit values of nonmarket goods [35,41-45] and can be considered as a state-of-the-art survey-based technique in the field, consistent the economic welfare theory [46]. 
The application of CV to landscape and landscape amenities is also common [47]. Moreover, Dachary-Bernard, and Rambonilaza [48], stated that an evaluation of preferences and elicitation of WTP from citizens may help policymaking and land use planning, enabling decision-makers to be more fully informed about their preservation merits [46].

The basic concept of CV is to model the individuals' responses in a well-defined hypothetical scenario and obtain the WTP for preservation or improvement of nonmarket goods and services. Moreover, using CV means dealing directly with the whole value of the valuated nonmarket good, because this method uses a holistic approach [48].

Among all the CV studies in the literature, even in the recent years, several studies have been applying a single-bounded dichotomous elicitation approach [44], as suggested by Reference [41]. The present work also employs this approach due to its simplicity and convenience, even though it is less statistically efficient than other formats.

In the last years, even in the recent one, the most widespread elicitation methods used are the single and the double bounded formulation [44,49]. The single bounded procedure is easier to implement than the double bound, in particular, in data collection and estimation. On the other hand, the double bound is well known to be more efficient than the single bound estimator, despite certain inconsistency issues [50]. Moreover, Calia and Strazzera [49] found out that the difference between the two approaches tends to reduce as the sample size is increased and is often negligible for medium size samples (over 250 observations), in particular, if adequately pre-tested.

In this elicitation format, the respondents are asked to accept or refuse, like a referendum, a precise amount of money (called bid) to maintain or improve the expression of the assessed good. Each individual has an associated utility function $u(j, Y, S)$, where $j$ is a binary variable representing the good/service we want to evaluate: If $j$ is equal to 1 , the individual can benefit from the good, otherwise $\operatorname{not}(j=0) ; Y$ is the income, whilst $S$ is the vector of socio-economic characteristics of the individual. The model assumes that the utility of each person derives both from the good and from her/his income. Assuming that the utility is stochastic:

$$
u(j, Y, S)=v(j, Y, S)+e_{j}
$$

where $e_{j}$ is the stochastic error; $v$ is the deterministic component of the Utility and $j=(0,1)$. It was assumed that the individual accepts bid $\left(x_{j}\right)$ under the condition:

$$
v\left(1, Y-x_{j}, S\right)+e_{1} \geq v(0, Y, S)+e_{0}
$$

Therefore, because of Equation (2), the probability of a positive answer is:

$$
\operatorname{Pr}\left(y e s \mid x_{i}\right)=\operatorname{Pr}\left[v\left(1, Y-x_{j}, S\right)+e_{1} \geq v(0, Y, S)+e_{0}\right]
$$

As $e_{1}$ and $e_{0}$ are random variables with zero mean that are equally and independently distributed Equation (3) can be specified with respect to the utility variation as follows:

$$
\operatorname{Pr}\left(y e s \mid x_{i}\right)=F_{n}(\Delta v)
$$

where $F_{n}(\cdot)$ is the distribution function and $(\Delta v)=v\left(1, Y-x_{j}, S\right)-v(0, Y, S)$. Considering the willingness to pay of each individual at least equal to the submitted value $\left(x_{j} \leq W T P\right)$ probability of acceptance can be expressed by:

$$
\operatorname{Pr}\left(\text { yes } \mid x_{i}\right)=\operatorname{Pr}\left(W T P \geq x_{i}\right)=G_{W T P}\left(x_{i}\right)
$$


where $G_{W T P}(\cdot)$ is the cumulative distribution function of the causal variable Willingness to Pay (WtP). Assuming $F_{n}(\cdot)$ is specified as a logistic function, so the parametric evaluation used the logit distribution:

$$
\operatorname{Pr}\left(y e s \mid x_{i}\right)=F_{n}(\Delta v)=\frac{1}{1+e^{\Delta v}}
$$

Considering that Equation (6) is logistic, it is possible to calculate the average WTP as follows:

$$
E(W T P)=\frac{1}{-\beta} \ln \left(1+e^{\alpha}\right)
$$

while the median [51] is equal to

$$
E(W T P)=\frac{\alpha}{-\beta}
$$

$\mathrm{CV}$ is not a method immune to criticism and error. Over the years, the literature on the CV has included criticisms about several sources of bias, including information and eliciting effects, hypothetical, starting-point and strategic biases [46]. Two sources of bias have been discussed in particular in the literature: sampling error and error linked to the creation of the hypothetical market scenario [52]. However, distortions can be controlled by referring to some suggestions in the literature, such as those proposed by the so-called NOAA Panel [53].

Moreover, due to the qualitative nature of landscape, to avoid bias caused by unfamiliar respondents, the study elicited responses from residents already familiar with the agricultural landscape in Lithuania and provided descriptions and images as reference points to improve the conditions of landscape. An accurate representation of the landscape and its changes should be considered as content validity for the valuation study [54]. Next, as suggested by Molina et al. [55], to prevent bias due to the presence of the interviewer, the surveys were answered independently by the respondents. Additionally, to prevent bias regarding insufficient details, the survey incorporated a description and photos, and the interviewers provided answers to questions and clarifications.

The questionnaire for the survey was created after the literature analysis on agricultural landscape and its attributes. Following the [10], the agricultural landscape for this study was defined according to the following attributes: (1) Structural elements, including environmental features (flora and fauna, the habitats and ecosystems) and land use types, and cultural features such as hedges and farming buildings; (2) landscape functions such as living and working places, which provide different environmental goods and services; and (3) value of the landscapes, consisting of the costs to farmers for landscape maintenance and the value that the society attributes to these agricultural landscapes for their recreational and cultural values.

The main determining components of the value of agricultural landscape were considered as follows: (1) Biodiversity (which depends on natural resources, and the whole agroecosystem); (2) cultural and historical heritage, such as tradition and its elements of landscape management, and preservation of traditions, crafts, and other non-tangible heritage; (3) aesthetic value of the landscape and its suitability for recreation; (4) accessibility of the landscape; and (5) scientific and educational interests $[17,56]$.

The survey has three parts, as suggested by the pioneering work of [57]. The first part comprises the description of the main characteristics of the Lithuanian landscape, followed by the investigation of the respondents' view and familiarity of the role of agriculture in the creation of landscape goods and services. The questionnaire presented Likert type and multiple-choice questions. The second part comprises the elicitation of the WTP for landscape services, using an annual payment as suggested by [58]. Three levels of the bid have been chosen and submitted to three different groups of respondents: 12,24 , and 48 EUR for the years proposed as the additional 5 years of a family tax that specifically addressed landscape preservation. The proposed bids were selected according to the previous study on agroecosystem services, where the agricultural landscape was selected as one attribute and for 
which the WTP was estimated [1]. Respondent-related demographic and socioeconomic characteristics completed the questionnaire.

\section{Results}

A pre-test in February-March 2017 was performed. The questionnaire was given to Lithuanian local residents. The pre-test allowed us to make adjustments to the questionnaire regarding the first part and to set the bids. In particular, we proposed both single and double bounded formats and found the former to be more suitable for the analysis in term of consistency of answers. Thus, we decided to use a single bound elicitation scheme. The main survey was conducted from June 2017-January 2018 in public places (i.e., post offices, waiting rooms at the hospital, public streets, mall and events), every seventh passing by as done by Rocchi et al. [59]. We focused on the events, where people would be willing to participate, people could be encountered, and the conditions to present the survey and clarify the questions/topic, if needed, were present. The research targeted only Lithuanian residents over 18 years old: Nonlocal residents were excluded. Therefore, the target population was about $2.3 \mathrm{mln}$. inhabitants. 600 questionnaires were distributed, 350 filled questionnaires were filled in and collected, 316 of those respondents provided complete and valid answers. Incomplete survey questionnaires were omitted from further data analysis. According to Israel [60] and the target population size, the number of questionnaires collected ensure a statistical error between $5 \%$ and $7 \%$.

The sample (Table 1) reflected the percentages of the population in terms of gender, area of residence, education and income. When considering the age, the sample is not representative because of the low willingness of older individuals to participate.

Table 1. Sociodemographic profile of respondents $(\mathrm{N}=316)$.

\begin{tabular}{|c|c|c|c|c|}
\hline \multirow{2}{*}{ Variables } & \multicolumn{2}{|c|}{ Study Sample } & \multicolumn{2}{|c|}{ General Population } \\
\hline & $\mathbf{N}$ & $\%$ & N (Thousands) & $\%$ \\
\hline \multicolumn{5}{|l|}{ Gender } \\
\hline Male & 117 & 37.0 & 1086.4 & 45.2 \\
\hline Female & 199 & 63.0 & 1319.4 & 54.8 \\
\hline \multicolumn{5}{|l|}{ Age } \\
\hline $18-39$ & 235 & 74.4 & 763.3 & 34.1 \\
\hline $40-65$ & 74 & 23.4 & 1023.2 & 45.8 \\
\hline over 65 & 7 & 2.2 & 449.2 & 20.1 \\
\hline \multicolumn{5}{|l|}{ Area of Residence } \\
\hline City & 208 & 65.8 & 1884.7 & 67.1 \\
\hline Village & 108 & 34.2 & 924.2 & 32.9 \\
\hline \multicolumn{5}{|l|}{ Education } \\
\hline High school & 154 & 48.7 & 747.9 & 37.3 \\
\hline Comparative, special secondary, and secondary & 162 & 51.3 & 1255.6 & 62.7 \\
\hline \multicolumn{5}{|l|}{ Income } \\
\hline$<350$ & 76 & 24.1 & 522.4 & 17.7 \\
\hline $351-600$ & 129 & 40.8 & 627.6 & 21.2 \\
\hline $601-900$ & 60 & 19.0 & 743.7 & 25.2 \\
\hline$>900$ & 51 & 16.1 & 1063.0 & 36.0 \\
\hline
\end{tabular}

Notes: (1) Breakdown of the Lithuanian population by gender, age, and area of residence data obtained from the Lithuanian Statistics, 2018. (2) The data on the educational attainment of the population was obtained from the Lithuanian Statistics, 2017 (The data was taken from the Official Statistics portal Statistics Lithuania, available at https://www.stat.gov.lt/home). (3). The data about the income of Lithuanian population was obtained from the Survey of Households, 2018 [61].

Table 2 shows that approximately $65 \%$ respondents observed the positive impact of agricultural activities on the landscape, and approximately $20 \%$ of the respondents thought that agriculture negatively affects the landscape. 
Table 2. General attitudes and beliefs regarding the impacts of farming on the landscape.

\begin{tabular}{|c|c|c|c|c|c|}
\hline \multicolumn{6}{|c|}{ How Do You Rate the Impacts of Agriculture on Landscape (\%)? } \\
\hline Very good & No impact & & Bad & & Very bad \\
\hline 52.5 & 14.2 & & 18.7 & & 1.3 \\
\hline \multicolumn{6}{|c|}{ How Do You Rank the Impact of Agricultural Activity on These Elements of Landscape (\%)? } \\
\hline Elements & Very Positive & Positive & No Impact & Negative & Very Negative \\
\hline $\begin{array}{l}\text { The visual uniqueness of the area and its } \\
\text { aesthetic value }\end{array}$ & 21.8 & 46.2 & 14.6 & 15.2 & 2.2 \\
\hline Visual diversity & 12 & 50.3 & 21.8 & 14.2 & 1.6 \\
\hline $\begin{array}{l}\text { Biodiversity (evaluate the changes of wildlife, } \\
\text { and home animals, crops) }\end{array}$ & 16.5 & 41.1 & 20.3 & 17.7 & 4.4 \\
\hline Perennial meadows & 13 & 39.2 & 29.7 & 16.8 & 1.3 \\
\hline Water bodies and coasts & 19.9 & 39.6 & 13.9 & 22.2 & 4.4 \\
\hline $\begin{array}{l}\text { Recreational infrastructure and attractiveness } \\
\text { of recreational place }\end{array}$ & 14.9 & 38.3 & 28.2 & 17.7 & 0.9 \\
\hline $\begin{array}{l}\text { Objects of cultural and historical heritage } \\
\text { objects and their preservation }\end{array}$ & 21.8 & 34.5 & 23.1 & 16.5 & 4.1 \\
\hline \multicolumn{6}{|c|}{ Evaluate the Impact of Different Farming Subjects and Public Administration on the Formation of Landscape (\%) } \\
\hline Impactors & Very Big & Big & Average & Small & Very Small \\
\hline Farmers & 26.3 & 38.3 & 30.7 & 4.4 & 0.3 \\
\hline Businessmen (excluding farmers) & 14.6 & 28.2 & 38.9 & 12 & 6.3 \\
\hline communities & 10.8 & 30.7 & 41.1 & 14.9 & 2.5 \\
\hline Municipality institutions & 12.7 & 28.8 & 37.7 & 16.1 & 4.7 \\
\hline Governmental institutions & 17.7 & 25.9 & 33.5 & 15.5 & 7.3 \\
\hline
\end{tabular}

This study wanted to find out the opinion of the respondents regarding the agricultural activities conducted on different landscape elements; thus, they were asked to rank the impact. The answers indicated the following: Agriculture has the biggest positive impact on the visual uniqueness of the area, its aesthetic value (stated by approximately $70 \%$ of the respondents), and visual diversity due to the land use, farming practices, crop structure (stated by $62 \%$ of the respondents), and water bodies and coasts (approximately 60\%); the greatest portion of the respondents declared that agriculture has a positive impact on biodiversity; one fifth of the respondents recognised the negative impact of agricultural activity on the natural biodiversity of flora and fauna; approximately $27 \%$ of respondents stressed the negative impacts of agriculture on water bodies and coasts; approximately $21 \%$ of respondents mentioned objects of cultural and historical heritage and their preservation; approximately $19 \%$ of respondents mentioned recreational infrastructure and attractiveness of recreational place; and $18 \%$ of respondents noted preservation of perennial meadows. The following agricultural environment factors have the greatest substantial impact on the landscape: Coastwise management (as stated by $64 \%$ of the respondents), preservation of ecologically important territories (as stated by approximately $62 \%$ of the respondents), farming styles and intensiveness (as stated by approximately $60 \%$ of the respondents), preservation of natural and historical objects (as stated by $59 \%$ of the respondents), and land use (as stated by $53 \%$ of the respondents).

The majority of the respondents (63\%) believed that farmers should be encouraged by payments to be interested in landscape management; however, approximately $34 \%$ stated it would be better to prevent their harmful farming practices and decrease their non-willingness to preserve the landscape. Three percent of the respondents answered that additional actions could be taken to encourage farmers' interest in landscape management, compliment environmentally friendly farming, let them participate in educational programmes, or establish sustainable farming practices. More than $80 \%$ of the respondents agreed that supporting agriculture is a good tool to improve the agricultural landscape.

We run two models: One based on only the proposed bid as explanatory variable and a respondent's socioeconomic characteristics model [47] and including the following variables: Net monthly family income, age, gender, and presence of children aged under 18 in the family. As respondent's income 
has a relatively strong positive correlation to the level of education, the latter is not included in the model [47]. The upper part of Table 3 reports the results of the first model, while in the lower, results with the variables are presented.

Table 3. CV results.

\begin{tabular}{cccc}
\hline Dependent Variable & Coeff. & S.E. & $p$-Value \\
\hline Constant & 0.70539 & 0.25521 & 0.0057 \\
Bid & -0.02999 & 0.00795 & 0.0002 \\
n. & 316 & & \\
LL & -210.56167 & & \\
McFadden Pseudo Rsqd & 0.339 & & \\
AIC/N & 1.345 & & $p$-Value \\
\hline Explanatory Variables & Coeff. & S.E. & 0.0675 \\
net monthly family income & 0.15261 & 0.08346 & 0.0574 \\
Age & -0.02102 & 0.01106 & 0.0735 \\
gender & 0.46808 & 0.26152 & 0.0102 \\
presence of children/teenagers & 0.23216 & 0.13231 & 0.0273 \\
agricultural support, as a tool of seeking & 0.25946 & 0.1175 & 0.0152 \\
high level of visual variety & 0.38441 & 0.15828 & \\
\hline
\end{tabular}

Using Equations (7) and (8), we calculated the average and median WTP for preserving the current level of landscape services, excluding the protest zero (Table 4). However, we considered the median one, as it is more precise then the average value [51]. The value is equal to $23.59 € /$ year per family, in the model with only the constant and the tax proposed as explanatory variables.

Table 4. Willingness to Pay for preserving the current level of landscape services.

\begin{tabular}{cc}
\hline & $\boldsymbol{\epsilon} /$ Year \\
\hline $\mathrm{WTP}_{\text {avarage }}$ & 36.91 \\
$\mathrm{WTP}_{\text {median }}$ & 23.59 \\
\hline
\end{tabular}

Considering the second model which includes explanatory variables, every EUR 100 of income increase on average, ceteris paribus, the value of WTP rise by EUR 4.61. This result is expected because it is in line with the economic theory and previous studies [47,52]. Further, we observe a higher WTP from parents: Ceteris paribus, in families with children, the WTP is EUR 1.31 higher than in childless families. We expected this result because of the literature [62]. We also observe a slightly higher WTP in women (EUR 0.74), which is in line with the literature: Evidence regarding this phenomenon remains scant, but we observe that women expressed a greater appreciation for the landscape [63]. By contrast, as age increased, the WTP decreased. Respondents who greatly appreciate the variety and visual diversity of agriculture also have a higher WTP (EUR 4.47 more), and the people who think that agricultural should be supported as a tool to improve the condition of landscape (EUR 1.04 more).

\section{Discussion}

The analysis has shown that the understanding and valuing of public goods and ecosystem services from the agricultural landscape is affected by different factors, such as age, social, and economic status, education, area of residence (substantial differences are observed between rural and urban residents), and environmental knowledge. Notably, residents from different countries may also have different preferences for agricultural landscape goods. These opinions and preferences are formed by long-standing conditions and periods.

The value obtained by this research is significantly higher than another study based on the Lithuanian preferences [1], where agricultural landscape was evaluated as one of the groups of 
ecosystem services. In that study, which applied CE with a latent class model instead of CV, the maximum value of WTP for landscape was equal to $12.2 € /$ years per family. As supported by the literature, the results indicated that socioeconomic characteristics impacted respondents' WTP for agricultural landscape services [27,59]. For instance, as in other studies [27,42], we have found that the WTP for agricultural landscape services is influenced primarily by gender and age. Our analysis has suggested that particularly younger people and women have higher WTP for the improvement of the agricultural landscape.

This study has also found that family income has a substantial effect on respondents' preferences regarding the agricultural landscape, because respondents with higher household income were willing to pay more for agricultural landscape services. Our previous research [1] did not demonstrate any statistically significant interactions among the attributes with income assessing the benefit of the agroecosystem services for a Lithuanian case study. In some studies, for example see References [64,65], rural respondents have been less willing to support the preservation of the agricultural landscape. However, in both of our studies, we did not observe any clear connection with the variable of rural/urban residence. Individuals who did not agree to pay for improvements to the agricultural landscape stated reasons similar to other studies [14], such as mistrust in governmental spending or indifference regarding the preservation of the agricultural landscape [59] and being unwilling to contribute due to low income $[14,66,67]$.

We found that approximately half of the respondents were unwilling to pay for the agricultural landscape services stated that they did not earn a sufficient amount of money to support the improvements to the agricultural landscape, approximately one third was unsure if the money would be allocated appropriately, and the remaining share of the respondents were not really interested in the agricultural landscape issues.

To sum up, our findings show substantial support for the maintenance of the agricultural landscape by the Lithuanian citizens, which is in line with the literature [34,68]. In view of the location of the research, we argue that the local population, in general, appreciated the impact of the EU support for landscape maintenance improvement, biodiversity preservation, conditions for rural tourism development, and increases in the rural population income. Evaluation results for the WTP for agricultural landscape services can be interpreted as the evidence of the expedience of the EU 'Agri-Environment and Climate' measures related to landscape maintenance. Following the evaluation of the residents' WTP for agricultural landscape services, it will be possible to improve the economic support system, based on society demand, which could motivate farmers to produce safe and high-quality food and other landscape and environmental services. The evaluation of agricultural landscape services is important for the modelling of the CAP agri-environmental measures and could reveal the potential for local economic development, for example, to identify the providing agricultural landscape services localities, which are connected to the development of economic activities such as rural tourism. Development of such agricultural landscape services could make the rural community less dependent on agricultural activities, changes in prices of agri-food products, or other economic declines [69].

\section{Conclusions}

The study revealed that Lithuanian residents are concerned about maintenance of agricultural landscape services, which are in high demand. The results of the application CV have demonstrated that the majority of the Lithuanian residents have a WTP for agricultural landscape services and are ready to pay additional taxes for positive changes in the natural environment and landscape. The results have highlighted that different socioeconomic characteristics, such as family income, age, gender, education, children under 18 years in the family, area of residence, and environmental knowledge affect residents' WTP for agricultural landscape services. The presence of children under 18 in the family and the positive attitude regarding agricultural support increases the WTP, and a higher income. On the contrary, growing age decreases the WTP. 
Moreover, the study has revealed a positive impact of CAP agri-environmental schemes as a result of the country's recent accession to the European Union, on the visual uniqueness of the area and its aesthetic value, visual diversity, land use, farming practices, crop structure, water bodies, and coasts. Lithuanian residents' acceptance was very positive and influenced their WTP for agricultural landscape services. Therefore, we assert that the CAP policy effects the uniqueness and variety of agricultural landscape services in Lithuania, and farmers should be motivated by agri-environmental payments in terms of their interest in landscape management and the creation of agricultural landscape services.

Author Contributions: The authors equally contributed to the current research paper. B.V. wrote the Introduction section, A.N. together with L.R. the Materials and Methods and Results. All the authors share and wrote the Discussion and Conclusions.

Funding: This research received no external funding.

Conflicts of Interest: The authors declare no conflict of interest.

\section{References}

1. Novikova, A.; Rocchi, R.; Vitunskienè, V. Assessing the benefit of the agroecosystem services: Lithuanian preferences using a latent class approach. Land Use Policy 2017, 68, 277-286. [CrossRef]

2. Council of Europe. European Landscape Convention. Florence. 2000. Available online: https://rm.coe.int/ 1680080621 (accessed on 23 July 2018).

3. Santos, J.L.; Madureira, L.; Ferreira, A.C.; Espinosa, M.; Paloma, S.G. Building an empirically-based framework to value multiple public goods of agriculture at broad supranational scales. Land Use Policy 2016, 53, 56-70. [CrossRef]

4. Dissart, J.C. Landscapes and Regional Development: What Are the Links? Cahiers d'Economie et de Sociologie Rurales (INRA): Paris, France, 2007.

5. Zasada, I.; Hafner, K.; Schaller, L.; van Zanten, B.T.; Lefebvre, M.; Malak-Rawlikowska, A.; Nikolov, D.; Rodriguez-Entrena, M.; Manrique, R.; Ungaro, F.; et al. A conceptual model to integrate the regional context in landscape policy, management and contribution to rural development: Literature review and European case study evidence. Geoforum 2017, 82, 1-12. [CrossRef]

6. Almeida, M.; Loupa-Ramos, I.; Menezes, H.; Carvalho-Ribeiro, S.; Guiomar, N.; Pinto-Correia, T. Urban population looking for rural landscapes: Different appreciation patterns identified in Southern Europe. Land Use Policy 2016, 53, 44-55. [CrossRef]

7. Torquati, B.; Tempesta, T.; Vecchiato, D.; Venanzi, S.; Paffarini, C. The Value of Traditional Rural Landscape and Nature Protected Areas in Tourism Demand: A Study on Agritourists' Preferences. Landsc. Online 2017, 53, 1-18. [CrossRef]

8. Bastian, O.; Grunewald, K.; Syrbe, R.U.; Walz, U.; Wende, W. Landscape services: The concept and its practical relevance. Landsc. Ecol. 2014, 29, 1463-1479. [CrossRef]

9. Fagerholm, N.; Käyhkö, N.; Ndumbaro, F.; Khamis, M. Community stakeholders' knowledge in landscape assessments-Mapping indicators for landscape services. Ecol. Ind. 2012, 18, 421-433. [CrossRef]

10. Peng, J.; Liua, Y.; Liub, Z.; Yang, Y. Mapping spatial non-stationarity of human-natural factors associated with agricultural landscape multifunctionality in Beijing-Tianjin-Hebei region, China. Agric. Ecosyst. Environ. 2017, 246, 221-233. [CrossRef]

11. Termoschuizen, J.W.; Opdam, P. Landscape services as a bridge between landscape ecology and sustainable development. Landsc. Ecol. 2009, 24, 1037-1052. [CrossRef]

12. Westerink, J.; Opdam, P.; van Rooij, S.; Steingröver, E. Landscape services as boundary concept in landscape governance: Building social capital in collaboration and adapting the landscape. Land Use Policy 2017, 60, 408-418. [CrossRef]

13. Prestegard, S.S. Multifunctional Agriculture and the Design of Policy Instruments: Application to the WTO Negotiations on Agriculture; Norwegian Agricultural Economics Research Institute, Centre of Food Policy: Oslo, Norway, 2004.

14. Berkel, D.B.; Verburg, P.H. Spatial quantification and valuation of cultural ecosystem services in an agricultural landscape. Ecol. Indic. 2014, 37, 163-174. [CrossRef] 
15. Ciaian, P.; Gomez, S. The Value of EU Agricultural Landscape; Agricultural \& Applied Economics Association, Publications Office of the European Union: Luxembourg, 2011. Available online: ftp://jrc.es/pub/EURdoc/ JRC65456.pdf (accessed on 15 June 2018).

16. Gobster, P.H.; Nassauer, J.I.; Daniel, T.C.; Fry, G. The shared landscape: What does aesthetics have to do with ecology? Landsc. Ecol. 2007, 22, 959-972. [CrossRef]

17. Lindhjem, H.; Reinvang, R.; Zandersen, M. Landscape Experiences as a Cultural Ecosystem Service in a Nordic Context. Concepts, Values and Decision-Making; Rosendahls-Schultz Grafisk: Copenhagen, Denmark, 2015; p. 189.

18. Paracchini, M.L.; Correia, T.P.; Loupa-Ramos, I.; Capitani, C.; Madeira, L. Progress in indicators to assess agricultural landscape valuation: How and what is measured at different levels of governance. Land Use Policy 2016, 53, 71-85. [CrossRef]

19. Wascher, D.M. Overview on Agricultural Landscape Indicators across OECD Countries. In Proceedings of the NIJOS/OECD Expert Meeting on Agricultural Landscape Indicators, Oslo, Noray, 7-9 October 2002.

20. Torquati, B.; Cecchini, L.; Venanzi, S.; Giacchè, G. Economic Analysis of the Traditional Cultural Terraced Olive-Growing Landscape and Participatory Planning Process. In World Terraced Landscapes: History, Environment, Quality of Life; Springer: Cham, Switzerland, 2018; pp. 251-271.

21. Schaller, L.; Targetti, S.; Villanueva, A.J.; Zasada, I.; Kantelhardt, J.; Arriaza, M.; Bal, T.; Bossi Fedrigotti, V.; Giray, F.H.; Hafner, K.; et al. Agricultural landscapes, ecosystem services and regional competitiveness-Assessing drivers and mechanisms in nine European case study areas. Land Use Policy 2018, 76, 735-745. [CrossRef]

22. Yadav, L.P.; O'Neill, S.; Van Rensburg, T. Supporting the conservation of farm landscapes via the tourism sector. Econ. Soc. Rev. 2013, 44, 221-245. [CrossRef]

23. Kanianska, R. Agriculture and its impact on land-use, environment, and ecosystem services. Landsc. Ecol. 2016, 2-26. [CrossRef]

24. Kvakkestad, V.; Rorstad, P.K.; Vatn, A. Norwegian farmers' perspectives on agriculture and agricultural payments: Between productivism and cultural landscapes. Land Use Policy 2015, 42, 83-92. [CrossRef]

25. Tagliafierro, C.; Longo, A.; Eetvelde, V.; Antrop, M.; Hutchinson, W.G. Landscape economic valuation by integrating landscape ecology into landscape economics. Environ. Sci. Policy 2013, 32, 26-36. [CrossRef]

26. Fleischer, A.; Tsur, Y. The Amenity Value of Agricultural Landscape and Rural-Urban Land Allocation. J. Agric. Econ. 2009, 60, 132-153. [CrossRef]

27. Häfner, K.; Zasada, I.; van Zanten, B.T.; Ungaro, F.; Koetse, M.; Piorr, A. Assessing landscape preferences: A visual choice experiment in the agricultural region of Märkische Schweiz, Germany. Landsc. Res. 2018, 43, 846-861. [CrossRef]

28. Hahn, T.; Heinrup, M.; Lindborg, R. Landscape heterogeneity correlates with recreational values: A case study from Swedish agricultural landscapes and implications for policy. Landsc. Res. 2018, 43, 696-707. [CrossRef]

29. Swensen, G.; Jerpåsen, G.B. Cultural heritage in suburban landscape planning a case study in Southern Norway. Landsc. Urban Plan. 2008, 87, 289-300. [CrossRef]

30. Tengberg, A.; Fredholm, S.; Eliasson, I.; Knez, I.; Saltzman, K.; Wetterberg, O. Cultural ecosystem services provided by landscapes: Assessment of heritage values and identity. Ecosyst. Serv. 2012, 2, 14-26. [CrossRef]

31. Drake, L. The Swedish agricultural landscape-Economic characteristics, valuations and policy options'. Int. J. Soc. Econ. 1999, 26, 1042-1062. [CrossRef]

32. Johnston, R.J.; Duke, J.M. Willingness to pay for agricultural land preservation and policy process attributes: Does the method matter? Am. J. Agric. Econ. 2007, 89, 1098-1115. [CrossRef]

33. Kubičkova, S. Non-market evaluation of landscape function of agriculture in the PLA White Carpathians. Agric. Econ. 2004, 50, 388-393. [CrossRef]

34. Rewitzer, S.; Huber, R.; Grêt-Regamey, A.; Barkmann, J. Economic valuation of cultural ecosystem service changes to a landscape in the Swiss Alps. Ecosyst. Serv. 2017, 26, 197-208. [CrossRef]

35. Torres-Miralles, M.; Grammatikopoulou, I.; Rescia, A.J. Employing contingent and inferred valuation methods to evaluate the conservation of olive groves and associated ecosystem services in Andalusia (Spain). Ecosyst. Serv. 2017, 26, 258-269. [CrossRef]

36. Lietuvos Respublikos Žemès Fondas 2017 m. Sausio 1 d; Nacionalinè Žemès Tarnyba prie Žemès Ūkio Ministerijos: Vilnius, Lithuania, 2017. 
37. Lithuania-Rural Development Programme 2014-2020; Ministry of Agriculture of the Republic of Lithuania: Vilnius, Lithuania, 2014.

38. Etnografiniu Kaimu Gyventoju Gyvenimo Kokybès Analizè ir Ūkinès Veiklos Tyrimas; Lietuvos Agrarinès Ekonomikos Institutas: Vilnius, Lithuania, 2012.

39. Europos Komisija. ES biologinés Itvairovés Strategija iki 2020 m. 2011. Available online: http://ec.europa.eu/ environment/pubs/pdf/factsheets/biodiversity_2020/2020\%20Biodiversity\%20Factsheet_LT.pdf (accessed on 15 June 2018).

40. Dupras, J.; Laurent-Lucchetti, J.; Revéret, J.; DaSilva, L. Using contingent valuation and choice experiment to value the impacts of agri-environmental practices on landscapes aesthetics. Landsc. Res. 2018, 43, 679-695. [CrossRef]

41. Carson, R.T. Contingent Valuation-A Comprehensive Bibliography and History; Edward Elgar: Cheltenham, UK, 2004; p. 455.

42. Chen, B.; Qiu, Z.; Usio, N.; Nakamura, K. Conservation and contingent valuation of farming landscape amenities by visitors: A case study of terraced paddy felds in Central Japan. Paddy Water Environ. 2018, 16, 561-570. [CrossRef]

43. Damigos, D.; Menegaki, M.; Kaliampakos, D. Monetizing the social benefits of landfill mining: Evidence from a Contingent Valuation survey in a rural area in Greece. Waste Manag. 2016, 51, 119-129. [CrossRef]

44. Mueller, J.; Springer, A.; Lima, R. Willingness to pay for forest restoration as a function of proximity and viewshed. Landsc. Urban Plan. 2018, 175, 23-33. [CrossRef]

45. Rocchi, L.; Paolotti, L.; Cortina, C.; Boggia, A. Conservation of landrace: The key role of the value for agrobiodiversity conservation. An application on ancient tomatoes varieties. Agric. Agric. Sci. Procedia 2016, 8, 307-316. [CrossRef]

46. Cook, D.; Eirikssdottir, K.; Daviosdottir, B.; Kristofersson, D.M. The contingent valuation study of Heiomork, Iceland-Willingness to pay for its preservation. J. Environ. Manag. 2018, 209, 126-138. [CrossRef]

47. Verbic, M.; Slabe-Erker, R.; Klun, M. Contingent valuation of urban public space: A case study of Ljubljanica riverbanks. Land Use Policy 2016, 56, 58-67. [CrossRef]

48. Dachary-Bernard, J.; Rambonilaza, T. Choice experiment, multiple programmes contingent valuation and landscape preferences: How can we support the land use decision making process? Land Use Policy 2012, 29, 846-854. [CrossRef]

49. Calia, P.; Strazzera, E. Bias and efficiency of single versus double bound models for contingent valuation studies: A Monte Carlo Analysis. Appl. Econ. 2000, 32, 1329-1336. [CrossRef]

50. Kim, H.; Lim, S.; Yoo, S. Residential Consumers' Willingness to Pay price premium for renewable heat in south Korea. Sustainability 2019, 11, 1234. [CrossRef]

51. Cooper, J.; Loomis, J. Sensitivity of Willingness-to-Pay Estimates to Bid Design in Dichotomous Choice Contingent Valuation Models. Land Econ. 1992, 68, 211-224. [CrossRef]

52. Schlapfer, F.; Roschewitz, A.; Hanley, N. Validation of stated preferences for public goods; a comparison of contingent valuation survey response and voting behaviour. Ecol. Econ. 2004, 51, 1-16. [CrossRef]

53. Arrow, K.; Solow, R.; Portney, P.R.; Leamer, E.E.; Radner, R.; Schuman, H. Report of the NOAA Panel on Contingent Valuation; Federal Register: Washington, DC, USA, 1993.

54. Tagliafierro, C.; Boeri, M.; Longo, A.; Hutchinson, W.G. Stated preference methods and landscape ecology indicators: An example of transdisciplinarity in landscape economic valuation. Ecol Econ. 2016, 127, 11-22. [CrossRef]

55. Molina, J.R.; Rodriguez y Silva, F.; Herrera, M.A. Integrating economic landscape valuation into Mediterranean territorial planning. Environ. Sci. Policy 2016, 56, 120-128. [CrossRef]

56. Romstad, E.; Vatn, A.; Rorstad, P.K.; Soyland, V. Multifunctional Agriculture-Implications and Policy Design. Implications for Policy Design; Report No. 21; Agricultural University of Norway: Oslo, Norway, 2000; p. 140.

57. Willis, K.G.; Garrod, G.D. Valuing Landscape: A contingent valuation approach. J. Environ. Manag. 1993, 37, 1-20. [CrossRef]

58. Egan, K.j.; Corrigan, J.R.; Dwyer, D.F. Three reasons to use annual payments in contingent valuation surveys: Convergent validity, discount rates, and mental accounting. J. Environ. Plan. Manag. 2015, 72, 123-136. [CrossRef] 
59. Rocchi, L.; Cortina, C.; Paolotti, L.; Massei, G.; Fagioli, F.F.; Antegiovanni, P.; Boggia, A. Provision of ecosystem services from the management of Natura 2000 sites in Umbria (Italy): Comparing the costs and benefits, using choice experiment. Land Use Policy 2019, 81, 13-20. [CrossRef]

60. Israel, G.D. Determining Sample Size. Institute of Food and Agricultural Sciences (IFAS); University of Florida: Gainesville, FL, USA, 2013; Volume 6, pp. 1-5.

61. Survey of Households, 2018. Available online: https://www.lb.lt/lt/lfsb-apklausos-ir-apzvalgos\#ex-1-5 (accessed on 15 June 2018).

62. Dupont, D.P. Do children matter? An examination of gender differences in environmental valuation. Ecol. Econ. 2004, 49, 273-286. [CrossRef]

63. Yang, Y.C.E.; Passarelli, S.; Lovell, R.J.; Ringler, C. Gendered perspectives of ecosystem services: A systematic review. Ecosyst. Serv. 2018, 31, 58-67. [CrossRef]

64. Arriaza, M.; Gomez-Limon, J.A.; Kallas, Z.; Nekhay, O. Demand for non-commodity outputs from mountain olive groves. Agric. Econ. Rev. 2008, 9, 5-23.

65. Baskaran, R.; Cullen, R.; Colombo, S. Estimating values of environmental impacts of dairy farming in New Zealand. N. Z. J. Agric. Res. 2009, 52, 377-389. [CrossRef]

66. Colombo, S.; Hanley, N.; Calatrava-Requena, J. Designing policy for reducing the off-farm effects of soil erosion using choice experiments. J. Agric. Econ. 2005, 56, 81-95. [CrossRef]

67. Jianjun, J.; Rui, H.; Wenyu, W.; Haozhou, G. Valuing cultivated land protection: A contingent valuation and choice experiment study in China. Land Use Policy 2018, 74, 214-219. [CrossRef]

68. Soliva, R.; Bolliger, J.; Hunziker, M. Differences in preferences towards potential future landscapes in the Swiss Alps. Landsc. Res. 2010, 35, 671-696. [CrossRef]

69. Schippers, P.; Heide, C.M.; Koelewijn, H.P.; Schouten, M.A.H.; Smulders, R.J.M.; Cobben, M.M.P.; Sterk, M.; Vos, C.C.; Verboom, J. Landscape diversity enhances the resilience of populations, ecosystems and local economy in rural areas. Landsc. Ecol. 2015, 30, 193-202. [CrossRef]

(C) 2019 by the authors. Licensee MDPI, Basel, Switzerland. This article is an open access article distributed under the terms and conditions of the Creative Commons Attribution (CC BY) license (http://creativecommons.org/licenses/by/4.0/). 